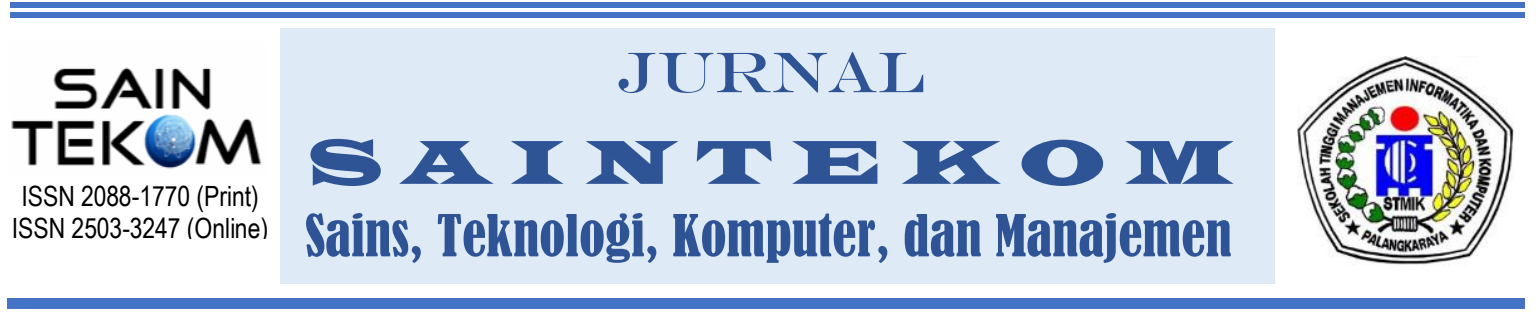

\title{
SISTEM PEMELIHARAAN MENARA BTS (BASE TRANSCEIVER STATION) BERBASIS MOBILE
}

\author{
*Adi Sucipto ${ }^{1}$, Hufajar Wiliam David ${ }^{2}$ dan Sampurna DR ${ }^{3}$, Syaiful Ahdan 4 \\ 1,4)Program Studi Teknologi Informasi Fakultas Teknik Dan Ilmu Komputer \\ ${ }^{2,3)}$ Program Studi Informatika Fakultas Teknik Dan Ilmu Komputer \\ Universitas Teknokrat Indonesia Bandar Lampung \\ Email: adi.sucipto@teknokrat.ac.id, hufajarwiliamdavid.telesys@gmail.com, \\ sampurna.go@teknokrat.ac.id, syaifulahdan@teknokrat.ac.id
}

\begin{abstract}
The development of mobile device technology, especially Android applications, is growing very significantly. The focus of this research is how to build a mobile-based BTS (Base Transceiver Station) tower maintenance system. This system was built to simplify and speed up the documentation and reporting process for BTS tower maintenance, thereby minimizing loss and duplication of documentation files when performing maintenance. This system is built using the Java programming language with a Firebase database. The system development method used is Extreme Programming. System testing using ISO 25010 testing using three testing aspects, with the results: $100 \%$ functionality aspect, $89.00 \%$ usability, and 5.4\% CPU usage performance efficiency. Tests were carried out on 5 Android Mobile devices with different specifications. From the results of testing on respondents using a Likert measurement scale, it was obtained an average of $94.5 \%$. Based on this, it can be concluded that the system is very good/very feasible to use and provides solutions to the problems faced.
\end{abstract}

Keywords: ISO 25010, Maintenance, Base Transceiver Station, Mobile, Extreme Programming.

\section{ABSTRAK}

Perkembangan teknologi perangkat bergerak (mobile), khususnya aplikasi Android berkembang sangat signifikan. Fokus penelitian ini adalah bagaimana membangun sistem pemeliharaan menara BTS (Base Transceiver Station) berbasis Mobile. Sistem ini dibangun untuk mempermudah dan mempercepat proses dokumentasi dan pelaporan pemeliharaan menara BTS, sehingga meminimalisir kehilangan dan duplikasi file dokumentasi saat melakukan perawatan. Sistem ini dibangun menggunakan bahasa pemrograman Java dengan database Firebase. Metode pengembangan sistem yang digunakan adalah Extreme Programming. Pengujian sistem menggunakan pengujian ISO 25010 menggunakan tiga aspek pengujian, dengan hasil: aspek fungsionalitas $100 \%$, usability $89,00 \%$, dan efisiensi kinerja penggunaan CPU 5,4\%. Pengujian dilakukan pada 5 perangkat Mobile Android dengan spesifikasi yang berbeda. Dari hasil pengujian pada responden dengan menggunakan skala pengukuran Likert, didapatkan rata-rata 94,5\%. Berdasarkan hal tersebut dapat disimpulkan 
bahwa sistem sangat baik/sangat layak digunakan dan memberikan solusi dari permasalahan yang dihadapi.

Kata Kunci: ISO 25010, Pemeliharaan, Base Transceiver Station, Mobile, Extreme Programming.

\section{PENDAHULUAN}

Base Transceiver Station (BTS)

adalah Tower adalah menara yang terbuat dari rangkaian besi atau pipa baik segiempat atau segitiga, atau hanya berupa pipa panjang/tongkat, yang bertujuan untuk menempatkan antena dan radio pemancar maupun penerima gelombang telekomunikasi dan informasi (Ismail, et al., 2015). Piranti komunikasi penerima sinyal BTS bisa telepon, telepon seluler, jaringan nirkabel sementara operator jaringan yaitu Global System for Mobile Communications (GSM), Code Division multiple access (CDMA), atau Time division multiple access (TDMA). Pada penelitian (Lim, 2015), selama lima tahun terakhir, perangkat mobile, seperti smartphone, dan tablet telah jauh lebih populer daripada perangkat desk-based tradisional seperti komputer pribadi dan laptop. Perawatan dan pemeliharaan atau disebut maintenace adalah semua tindakan teknik dan administratif yang dilakukan untuk menjaga agar kondisi mesin/peralatan tetap baik dan dapat melakukan segala fungsinya dengan baik,efisien, dan ekonomi sesuai dengan tingkat keamanan tinggi. Pada penelitian (Arjanggi, et al., 2012), menara telekomunikasi adalah bangunan-bangunan untuk kepentingan umum yang didirikan di atas tanah, atau bangunan yang merupakan satu kesatuan konstruksi dengan bangunan gedung yang dipergunakan untuk kepentingan umum yang struktur fisiknya dapat berupa rangka baja yang diikat oleh berbagai simpul atau berupa bentuk tunggal tanpa simpul, dimana fungsi, desain dan konstruksinya disesuaikan sebagai sarana penunjang menempatkan perangkat telekomunikasi. Penelitian ini menggunakan fitur google maps, pada penelitian (Octaviansyah, et al., 2019) Google Maps adalah sebuah jasa peta global virtual gratis dan online yang disediakan oleh Google dan dapat ditemukan di http://maps.google.com. Google Maps memberikan layanan untuk menunjukkan jalan-jalan yang ada di seluruh dunia. Ada penelitian yag berkaitan dengan perawatan antara lain pada penelitian (Sudarmono, 2017) 
yang meneliti bagaimana Pembuatan aplikasi monitoring perawatan dan pemeliharaan mesin central utility di PT. Phapros Tbk menggunakan software berbasis Java dan XML. Pada penelitian (Ginting, 2014), berisi tentang bagaimana merancang dan membangun perangkat pemantau kondisi shelter BTS secara online agar kondisi sejumlah shelter BTS dapat diketahui secara cepat melalui internet. Pada penelitian (Subhan \& Mulyani, 2017), berisi tentang bagaimana membangun sebuah program aplikasi berbasis mobile device yang dapat diterapkan untuk memantau dan memelihara Base Transceiver Station. Saat ini, pemantauan kondisi BTS milik PT Bach multi Global(BMG) dilakukan secara langsung. Dalam pendokumentasian kondisi BTS dan pembuatan laporan masih bersifat konvensional. Saat dokumentasi belum terorganisasi dengan baik sehingga sering terjadi kehilangan file foto, sehingga menyebabkan Engineer harus kembali ke lokasi menara untuk pendokumentasian kembali. Hal tersebut berakibat pengeluaran biaya operasional bertambah. Saat pembuatan laporan masih menggunakan Ms.Excel, sehingga belum tersimpan di database.
Semua hal tersebut mengakibatkan pembuatan laporan pemeliharaan sering terlambat melebihi perjanjian kontrak yang telah disepakati. PT BMG selaku kontraktor yang dipilih pemilik menara telekomunikasi sering mendapatkan hukuman (pinalty) karena keterlambatan pengumpulan laporan hasil pemeliharaan menara tersebut. Apabila pemilik BTS hanya mempunyai sedikit BTS, maka laporan hasil pemantauan dan pemeliharaan BTS masih bisa diketahui oleh pemilik BTS dengan cepat, tepat dan tidak tertukartukar. Tetapi jika memiliki banyak BTS, akan merasa kesulitan untuk mengetahui secara cepat dan tepat hasil laporan dari Engineer, karena data yang didapat dari Engineer sering keliru dan tertukar. Solusi yang ditawarkan dengan membangun perangkat alat bantu untuk mengambil keputusan berkaitan dengan penanganan gangguan. Maka diperlukan suatu sistem pelaporan yang cepat dan tepat sehingga pemilik BTS bisa dengan cepat dan mudah mendapatkan hasil dari laporan pemeliharaan tersebut. Sistem yang dibangun dapat menghindari pinalty yang harus dibayar PT BMG kepada perusahaan pemilik menara telekomunikasi, dikarenakan 
keterlambatan mengirimkan laporan. Penelitian ini bertujuan menghasilkan sebuah sistem pemeliharaan menara telekomunikasi dan BTS PT Bach Multi Global berbasis Android mobile. Sistem ini dapat membantu proses pemantauan dan pemeliharaan bisa lebih mudah lebih cepat dan file foto tersimpan di database. Semua ini dikarenakan dengan adanya sistem berbasis mobile yang digunakan oleh Engineer dalam memberikan data laporan secara langsung melalui sistem tersebut.

\section{METODE}

$$
\text { Pada penelitian ini }
$$
menggunakan metode pengembangan sistem Extreme Programming (XP). Extreme Programming (XP) adalah metodologi pengembangan perangkat lunak yang ditujukan untuk meningkatkan kualitas perangkat lunak dan tanggap terhadap perubahan kebutuhan pelanggan. Extreme Programming (XP) adalah metode pengembangan software yang cepat, efisien, beresiko rendah, fleksibel, terprediksi, scientific, dan menyenangkan. Menurut Pressman pada penelitian (Putra AD, 2020), tahapantahapan dari Extreme Programming yaitu: Planning, Design, Coding, Testing.

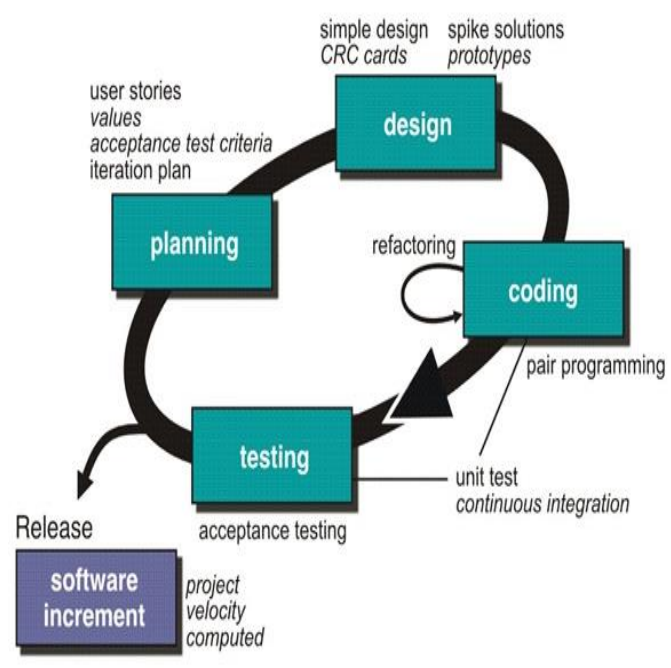

Gambar 1 Tahapan extreme programming (Sumber: Pressman, 2015)

\section{a. Perencanaan (planning)}

Pada tahap ini peneliti melakukan perencanaan berdasarkan dari permasalahan yang ada dilapangan dan studi literatur. Penulis melakukan interview dan observasi di lapangan, penulis merekam segala kebutuhan pengguna dan permasalahan yang ada. Dari proses tersebut didapatkan permasalahan pada saat pelaporan dan dokumentasi hasil dari perawatan BTS. Adapun beberapa teori pendukung untuk penelitian ini, antara lain sebagai berikut.

\section{b. Tahap Desain}

Pada tahap ini adalah dari kelanjutan dari tahap perencanaan. Berdasarkan pada perencanaan sebelumnya, maka telah dibuatkan desain sebagai berikut. 


\section{1) Use Case Diagram}

Pada gambar 2 menunjukkan use case dari sistem yang diajukan.

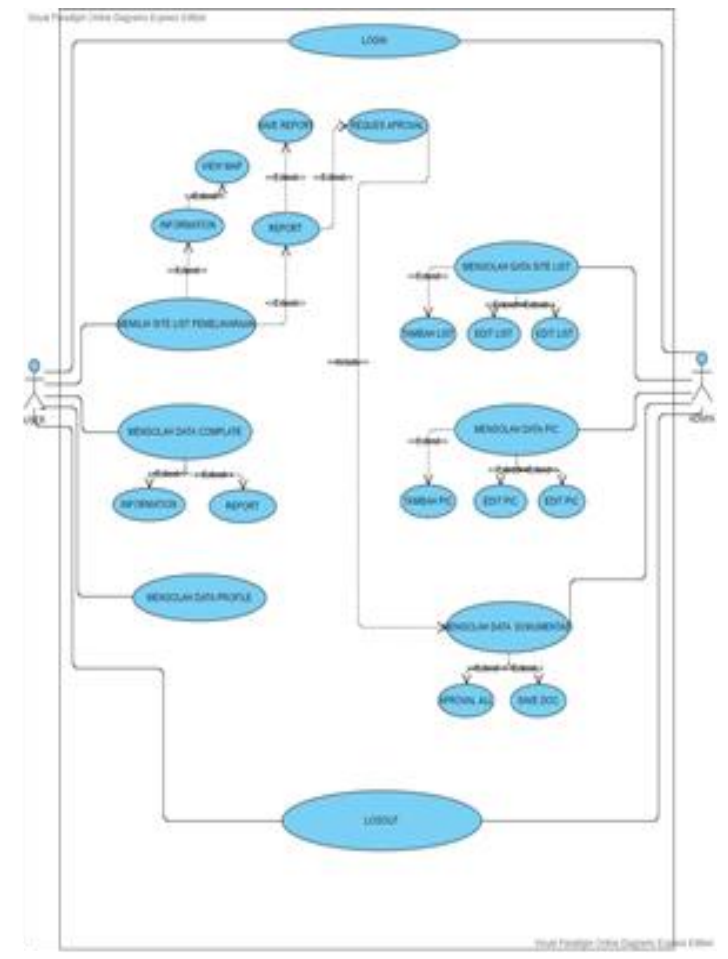

Gambar 2 Use Case Diagram Sistem Pemeliharaan Menara Telekomunikasi dan BTS(Base Transceiver Station) pada PT. Bach Multi Global

$$
\text { Use Case Diagram }
$$

mendeskripsikan interaksi antara satu atau lebih aktor yang akan di buat pada Sistem pemiharaan menara telekomunikasi dan BTS Base Transceiver Station PT Bach Multi Global. Terdapat dua aktor yang terlibat di dalam sistemn yaitu admin dan user, user dalam hal ini adalah teknisi perawatan yang memonitoring menara.

\section{2) Activity Diagram}

Pada gambar 3 menunjukkan activity diagram dari sistem yang diajukan yang merupakan alur kerja Sistem pemiharaan menara telekomunikasi dan BTS Base Transceiver Station PT Bach Multi Global.

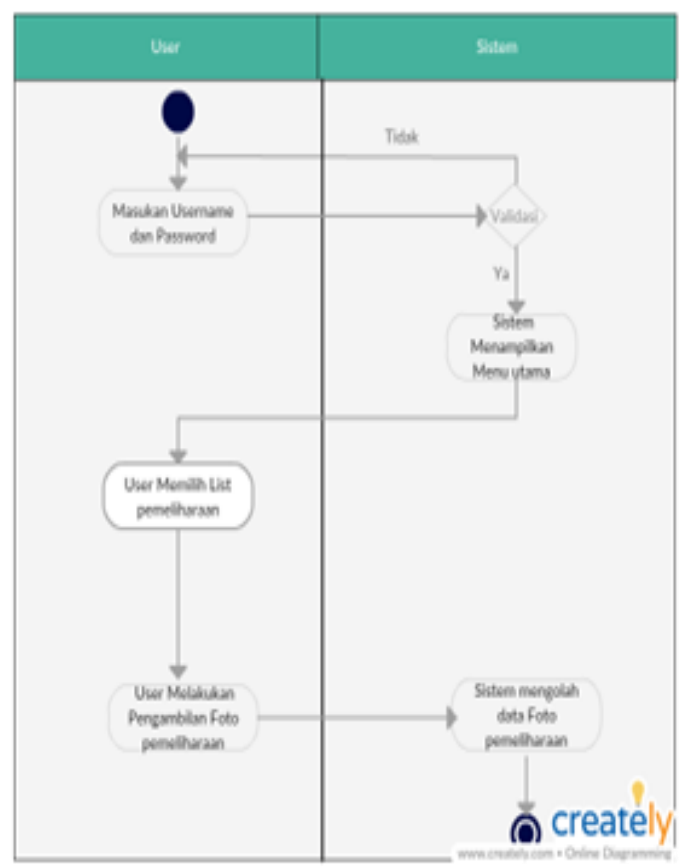

Gambar 3 Activity Diagram Sistem Pemeliharaan Menara Telekomunikasi dan BTS(Base Transceiver Station) pada PT. Bach Multi Global

\section{c. Tahap Implementasi (Coding)}

Setelah tahap perancangan, langka selanjutnya adalah melakukan implementasi. Adapun tahapannya adalah pembuatan database menggunakan firebase, membangun sistem dengan menggunakan bahasa pemrograman Java. 


\section{d. Pengujian (Testing)}

Pada penelitian ini, pengujian dilakukan menggunakan ISO 25010, yang dibuat oleh International Organization for Standarization (ISO) dan International Electrotechnical Commission (IEC). ISO 25010 menggantikan standar ISO/IEC 9126. Model kualitas produk ISO 25010 mengkategorikan sifat kualitas produk menjadi delapan kualitas sebagai berikut Functionality, Reliability, Usability, Efficiency, Maintainability Portability, Security, Compatibility. Hasil pengujian kualitas merupakan hasil pengujian dari reponden yang mingisi kuesioner untuk pengujian kualitas perangkat lunak sistem pemeliharaan menara telekomunikasi dan BTS PT.BMG berbasis android, semua memberikan jawaban kuesioner dengan valid. Tanggapan responden terhadap tingkat kualitas Sistem pemiharaan menara telekomunikasi dan BTS PT.BMG berbasis android berdasarkan jawaban responden terhadap indikator kualitas software menurut ISO 25010, dapat diukur menggunakan rumus berikut:

$\%$ Skor Aktual $=\frac{\text { skor aktual }}{\text { skor ideal }} \times 100 \%(1)$
Keterangan :

1. Skor aktual adalah jawaban seluruh responden atas kuesioner yang di ajukan.

2. Skor ideal adalah nilai tertinggi atau semua responden diasumsikan memilih jawaban dengan skor tertinggi. Menurut Narimawati pada penelitian (Nur, et al., 2019) persentase tanggapan responden dapat dilihat pada tabel 1 berikut.

Tabel 1 Presentase Tanggapan Responden

\begin{tabular}{|c|c|}
\hline $\begin{array}{l}\text { Jumlah } \\
\text { Skor }\end{array}$ & Kriteria \\
\hline $0.00-36.00$ & Tidak Baik / Tidak Layak \\
\hline $\begin{array}{ll}36.01 & - \\
52.00 & \end{array}$ & $\begin{array}{l}\text { Kurang Baik / Kurang } \\
\text { Layak }\end{array}$ \\
\hline $\begin{array}{l}52.01 \\
68.00\end{array}$ & Cukup Baik / Cukup Layak \\
\hline $\begin{array}{ll}68.01 & - \\
84.00 & -\end{array}$ & Baik / Layak \\
\hline $84.01-100$ & $\begin{array}{l}\text { Sangat Baik / Sangat } \\
\text { Layak }\end{array}$ \\
\hline
\end{tabular}

(Sumber: Nur dkk 2019)

dengan menggunakan tiga (3) aspek pengujian yaitu pengujian functionality, aspek pengujian usability, aspek pengujian Efficiency. Pengujian aspek functionalit, aspek usability dan aspek Efficiency dilakukan oleh Karyawan PT.Bach Multi Global.

\section{HASIL DAN PEMBAHASAN}

Tahap hasil dan pembahasan adalah implementasi yang dilakukan meliputi implementasi rancangan antarmuka (user interface) ke dalam 
bahasa pemrograman android dan pembahasan hasil pengujian.

\section{a. Hasil Implementasi}

Sesuai dengan rancangan desain interface yang sudah dibuat. Pada gambar 4, 5, 6, 7 dan 8 adalah tampilan hasil dari program yang dikembangkan.

1) Menu Utama User

Antarmuka menu utama menampilkan informasi menara telekomunikasi. Fungsi dari menumenu yang ada pada menu utama, yaitu menu progress untuk melihat informasi site list user dan melihaat informasi tentang menara telekomunikasi, complate untuk melihat site list menara yang telah dilakukan pemeliharaan. Tampilan form menu utama dapat dilihat pada gambar 4.

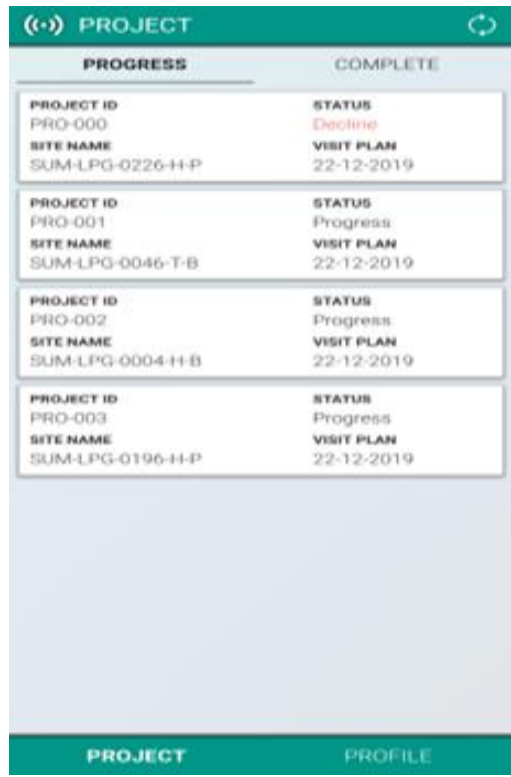

Gambar 4 Hasil Antarmuka Menu Utama pada User
2) Menu Utama Admin

Form Menu Utama Admin merupakan menu home halaman utama dijalankan oleh Admin.

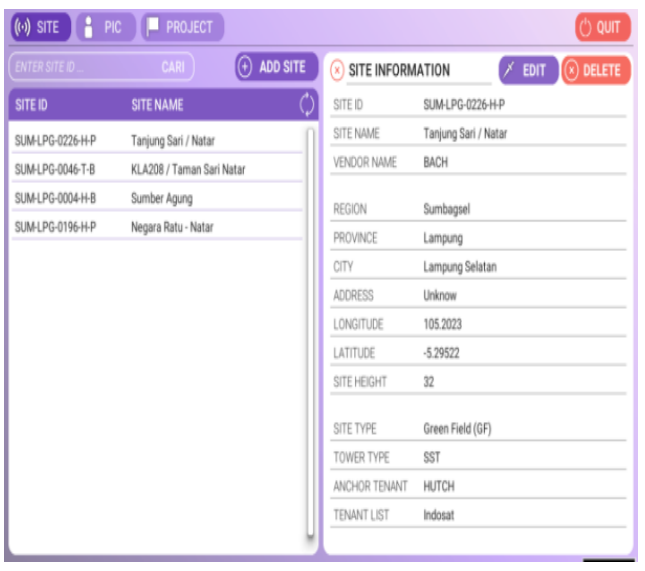

Gambar 5 Hasil Antarmuka Admin

3) Menu Report User

Menu Report User, digunakan untuk menyimpan foto di smartphone dan button request aproval untuk mengirim hasil foto-foto pemeliharaan menara dan menyimpan foto pemeliharaan.

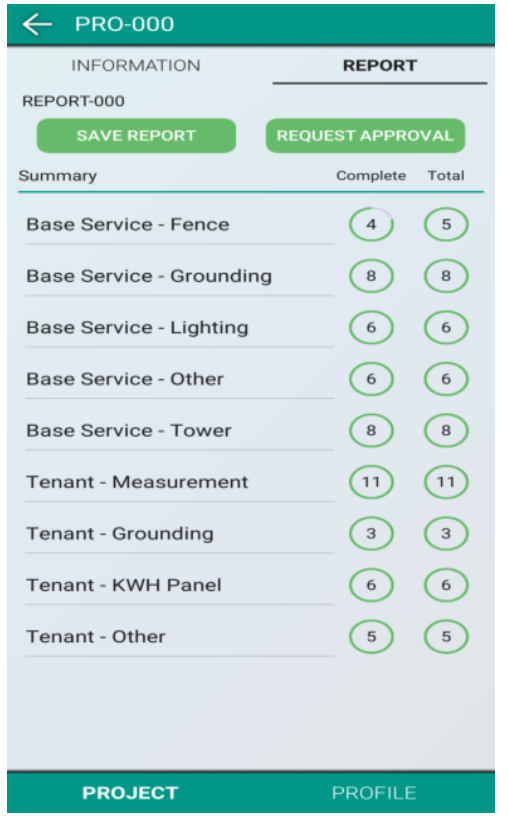

Gambar 6. Antarmuka Menu Report User 
4) Menu Base Service Fance

Menu Base Service Fance

menambahkan dan menampilkan

data pemeliharaan menara

telekomunikasi yang harus diambil

datanya oleh pengguna/teknisi.

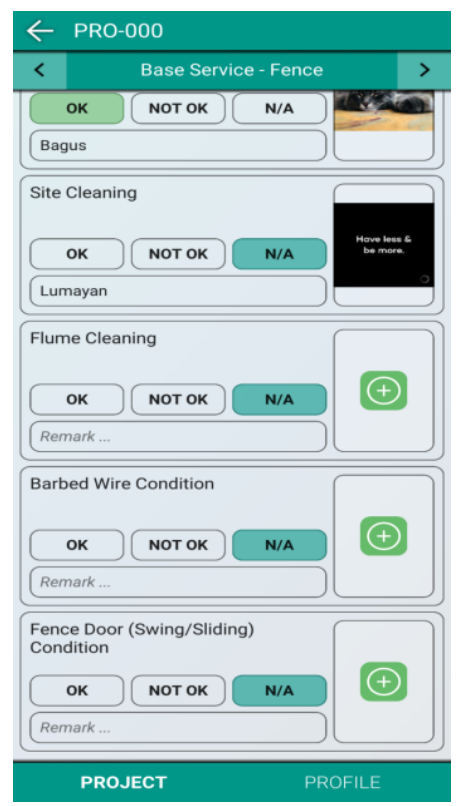

Gambar 7. Tampilan Form Sub Menu Base Service Fance User

5) Tampilan Maps Lokasi BTS

Pada Tampilan ini menjelaskan posisi BTS berada berdasarkan Map. Tampilan menggunakan fitur google map.

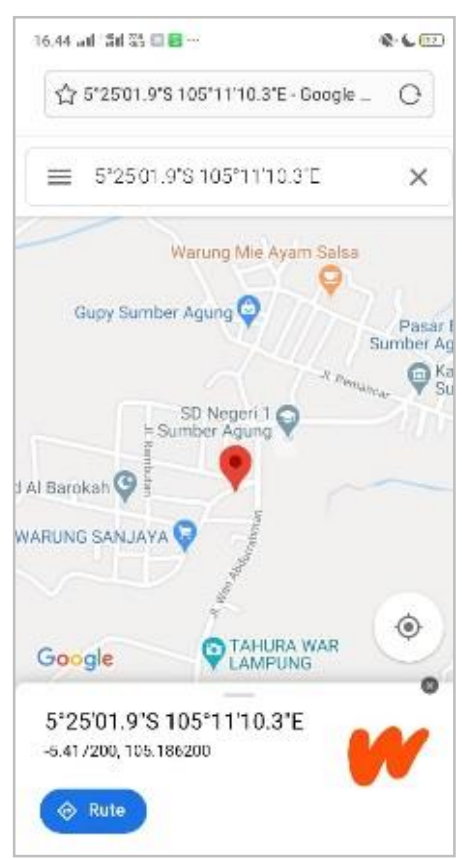

Gambar. 8 Tampilan Maps lokasi BTS

\section{b. Pembahasan Hasil Pengujian}

Tahap pengujian menggunakan ISO 25010. Berdasarkan hasil pengujian functionality, didapatkan nilai 100 dari 22 soal kuisioner yang diberikan ke responden. Nilai tersebut didapat dari persentase uji aspek functionality, berikut adalah hasil perhitungannya:

$$
=\frac{22}{22} \times 100 \%=100 \%
$$

Dari hasil perhitungan presentase uji aspek functionality di atas, dapat disimpulkan sistem pemiharaan menara telekomunikasi dan BTS PT.BMG berbasis android memperoleh hasil nilai $100 \%$, berarti sistem dapat bekerja dengan baik. Pada tabel 2 menunjukan hasil pengujian Usabilty. 
Tabel 2. Hasil Perhitungan Aspek Usability

\begin{tabular}{|c|c|c|c|c|c|c|c|c|c|c|c|c|c|}
\hline \multirow{3}{*}{$\begin{array}{c}\text { Kriteria } \\
\text { Jawaban }\end{array}$} & \multirow{3}{*}{ Bobot } & \multicolumn{11}{|c|}{ Usability } & \multirow{3}{*}{ TOTAL } \\
\hline & & \multicolumn{2}{|c|}{$\begin{array}{l}\text { Underst } \\
\text { anbility }\end{array}$} & \multicolumn{2}{|c|}{$\begin{array}{l}\text { Learn } \\
\text { ability }\end{array}$} & \multicolumn{4}{|c|}{ Operability } & \multicolumn{3}{|c|}{ Attractiveness } & \\
\hline & & 1 & & 3 & 4 & 5 & 6 & & 8 & 9 & 10 & 11 & \\
\hline SS & 5 & 3 & 4 & 4 & 4 & 5 & 4 & 3 & 5 & 3 & 4 & 4 & 43 \\
\hline $\mathrm{s}$ & 4 & 3 & 2 & 2 & 2 & 1 & 2 & 3 & 1 & 3 & 1 & 2 & 22 \\
\hline $\mathrm{N}$ & 3 & 0 & 0 & 0 & 0 & 0 & 0 & 0 & 0 & 0 & 1 & 0 & 1 \\
\hline TS & 2 & 0 & 0 & 0 & 0 & 0 & 0 & 0 & 0 & 0 & 0 & 0 & 0 \\
\hline STS & 1 & 0 & 0 & 0 & 0 & 0 & 0 & 0 & 0 & 0 & 0 & 0 & 0 \\
\hline \multicolumn{2}{|c|}{$\begin{array}{c}\text { Jumlah } \\
\text { Responden }\end{array}$} & 6 & 6 & 6 & 6 & 6 & 6 & 6 & 6 & 6 & 6 & 6 & \\
\hline \multirow{2}{*}{\multicolumn{2}{|c|}{ Skor Aktual }} & 23 & 28 & 28 & 28 & 29 & 23 & 24 & 29 & 27 & 27 & 28 & 294 \\
\hline & & 30 & 30 & 30 & 30 & 30 & 30 & 30 & 30 & 30 & 30 & 30 & 330 \\
\hline
\end{tabular}

Pada gambar 9 merupakan grafik persentase rata-rata hasil pengujian usability, yang diujikan kepada pengguna sistem yaitu admin dan user (teknisi). Berdasarkan perhitungan di atas dapat disimpulkan bahwa tingkat

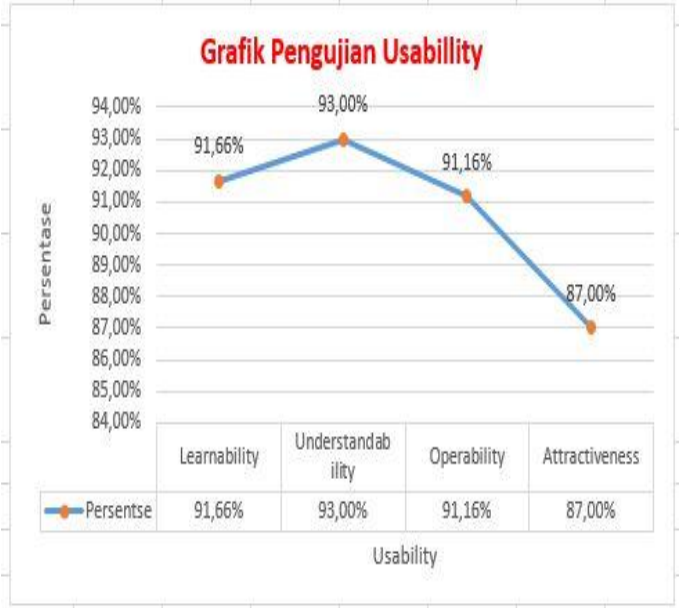

Gambar 9. Grafik Persentase rata-rata pengujian Usability

Pada penelitian ini, pengujian Performance Efficiency menggunakan tools Geekbench5 secara automation. Pengujian menggunakan 5 perangkat mobile yang berbeda merk dan spesifikasi, yang terdapat di tabel 3 .
Tabel 3 Hasil Uji Performance Efficiency

\begin{tabular}{|l|l|l|l|l|}
\hline Perangkat & $\begin{array}{l}\text { Sistem } \\
\text { Oprasi }\end{array}$ & CPU & Memory & Threads \\
\hline OPPO F9 & $\begin{array}{l}\text { Android } \\
9\end{array}$ & 7 & 28 & 18 \\
\hline VIVO V11 & $\begin{array}{l}\text { Android } \\
9\end{array}$ & 7 & 24 & 18 \\
\hline XIOMI 4x & 4.4 .2 & 4 & 20 & 4 \\
\hline $\begin{array}{l}\text { Samsung } \\
\text { A50 }\end{array}$ & 5.0 .2 & 5 & 28 & 18 \\
\hline $\begin{array}{l}\text { Oppo Find } \\
7 a(4.3)\end{array}$ & 4.3 .3 & 4 & 24 & 16 \\
\hline
\end{tabular}

Hasil pengujian dikelompokkan menjadi 3, dari segi penggunaan CPU, memory dan eksekusi thread. Berdasarkan seluruh uji performance efficiency yang sudah dilakukan, yang ditampilkan dalam tabel 3 di atas. Dari tabel tersebut dapat disimpulkan secara umum bahwa sistem dapat berjalan dengan baik tanpa mengalami memory leak yang mengakibatkan force close dan launch fail, sehingga sistem ini dikatakan "Layak".

\section{KESIMPULAN}

Sistem pemeliharaan menara telekomunikasi dan BTS Base Transceiver Station PT Bach Multi Global berbasis mobile android dibangun menggunakan Bahasa pemrograman Java dan XML dengan Tools Unity 3D serta database menggunakan Firebase database dari google platform. Pengujian kelayakan perangkat lunak menggunakan ISO 25010 dengan teknik kuesioner. Hasil pengujian dari aspek fungsional sistem 
diperoleh nilai 100\%, dari aspek usability pengguna diperoleh nilai $89,00 \%$, dan aspek performance efficiency dilakukan pada 5 perangkat Mobile Android dengan spesifikasi yang berbeda, dapat dilihat di tabel 3 . Pengujian berjalan dengan baik tanpa mengalami memory leak yang mengakibatkan force close dan launch fail. Dari hasil pengujian pada responden dengan menggunakan skala pengukuran Likert, didapatkan rata-rata $94,5 \%$. Berdasarkan hal tersebut dapat disimpulkan bahwa sistem sangat baik/sangat layak digunakan dan memberikan solusi dari permasalahan yang dihadapi.

\section{DAFTAR PUSTAKA}

Arjanggi, S., Wahyuni \& Soewardojo, 2012. Studi Perbandingan Struktur Tower BTS Tipe SST Kaki 4, Sst Kaki 3 Dan Monopole Dengan ketinggian 40m Yang Paling Effisien. Jurnal Teknik POMITS, 1(1), pp. 1-5.

Ginting, D., 2014. Rancang Bangun Perangkat Pemantau Shelter BTS. KOMPUTIKA - Jurnal Sistem Komputer UNIKOM, 2(2).

Ismail, N., Maharoni \& Lindra, I., 2015. Analisis

Perencanaan Pembangunan BTS (Base Transceiver Station) Berdasarkan Faktor Kelengkungan Bumi Dan Daerah Fresnel Di Regional Project
Sumatera Bagian Selatan. Jurnal Istek, 9(1).

Lim, S. H., 2015. Experimental comparison of hybrid and native applications for mobile systems. International Journal of Multimedia and Ubiquitous Engineering, 10(3), pp. 1-12.

Nur, A. A. R., Alam, A. R. P. \& Anggi, 2019. Pengaruh Kemasan Produk Susu Bear Brand Terhadap Keputusan Pembelian Konsumen Pada PT. Oze Power Switch Di Makassar. Movere Journal, 1(2), pp. 111-120.

Octaviansyah, A., Darwis, D. \& Surahman, A., 2019. Sistem Pencarian Lokasi Bengkel Mobil Resmi Menggunakan Teknik Pengolahan Suara Dan Pemrosesan Bahasa Alami. Jurnal Teknoinfo, 13(2), pp. 71-77.

Parwita, W. G. S. \& Putri, L. A. A. R., 2012. Komponen penilaian kualitas perangkat lunak berdasarkan software quality models. Semantik, 2(1).

Pressman, R., 2015. Rekayasa Perangkat Lunak: Pendekatan Praktisi Buku I. 1 ed. Yogyakarta: Andi.

Putra, A. D., 2020. Rancang Bangun Aplikasi E-Commerce Untuk Usaha Penjualan Helm. Jurnal Informatika dan Rekayasa Perangkat Lunak, 1(1), pp. 17-24.

Rosa, A. S. \& Shalahuddin, M., 2014. Terstruktur, R. P. L., \& Objek. 1 ed. Bandung: Informatika.

Subhan, F. \& Mulyani, A., 2017. Aplikasi Pemantauan dan Pemeliharaan Base Transceiver 
Station Berbasis Android. JITK

(Jurnal Ilmu Pengetahuan Dan

Teknologi Komputer), 3(1), pp. 5358.

Sudarmono, E., 2017. Rancang Bangun

Sistem Monitoring Perawatan Dan

Pemeliharaan Mesin Central Utility

Pt. Phapros, Tbk Di Mobile

Smartphone Berbasis Android 4.0

Menggunakan Software Eclipse

Kepler, Semarang: Jurusan Teknik

Elektro Universitas Semarang. 